Abstracta Iranica Abstracta Iranica

Revue bibliographique pour le domaine irano-aryen

Volume 29 | 2008

Comptes rendus des publications de 2006

Jostār-hā'ì dar sanad-šenāsī-ye fārsī. Vol. I, Bonyād-e pažūheš va tose'e-ye farhang-e vaqf, Tehrān, Našre Șā’en, 1385/2006, 167 p., index des termes.

Maria Szuppe

(2) OpenEdition

Journals

Édition électronique

URL : http://journals.openedition.org/abstractairanica/28662

DOI : 10.4000/abstractairanica.28662

ISSN : 1961-960X

Éditeur :

CNRS (UMR 7528 Mondes iraniens et indiens), Éditions de l'IFRI

Édition imprimée

Date de publication : 15 mai 2008

ISSN : 0240-8910

Référence électronique

Maria Szuppe, « Jostār-hāî dar sanad-šenāsì-ye fārsī. Vol. I, Bonyād-e pažūheš va tose'e-ye farhang-e vaqf, Tehrān, Našr-e Șā'en, 1385/2006, 167 p., index des termes. », Abstracta Iranica [En ligne], Volume 29 | 2008, document 206, mis en ligne le 15 septembre 2008, consulté le 26 septembre 2020. URL : http://journals.openedition.org/abstractairanica/28662 ; DOI : https://doi.org/10.4000/ abstractairanica.28662

Ce document a été généré automatiquement le 26 septembre 2020.

Tous droits réservés 


\title{
Jostār-hā'ī dar sanad-šenāsī-ye fārsī. Vol. I, Bonyād-e pažūheš va tose'e- ye farhang-e vaqf, Tehrān, Našr-e Șā'en, 1385/2006, 167 p., index des termes.
}

\author{
Maria Szuppe
}

1 Recueil rassemblant six articles d'Omīd Reḍāî̀, publiés entre 1381-1384/2002-2005 dans le périodique Mîrāt-e Jāvīdān [ci-après cité comme MJ], parfois avec des titres légèrement différents. Il s'agit de la recherche récente menée par ce spécialiste des documents d'archives, et consacrée au sanad-nevīsī, c'est-à-dire aux usages en vigueur dans les administrations de l'État safavide et qajar quant à la rédaction des documents divers (actes de vaqf, comptes, baux, actes d'achat-vente, etc.), ainsi qu'aux caractéristiques de ces documents. Ce volume, premier d'une série, contient deux parties (fașl) avec les articles concernant, respectivement, les époques safavide et qajare. Chacune des études reprises ici, dont l'intérêt est à la fois scientifique et documentaire, renferme une présentation et une analyse détaillées et annotées du document, suivie de son texte édité ainsi que de la reproduction en fac-similé du document original.

2 Partie I : 1. « Vaqf-nāme-ye Mīrzā Jalāl al-Dīn Ḥakīm Jonābādī », pp. 15-32 [= MJ, n 50, été 1384/2006, pp. 56-63] ; 2. "SāHูtār va moḥtavā-ye 'mețāl' dar dowre-ye șafaviye ", pp. 33-61 [MJ, n 47-48, automne-hiver 1383/2005-6, pp. 68-84] ; 3. «Nūzdah no'-e qabāle va sanad dar jong-e Huațți az dowre-ye șafaviye », pp. 63-106 [MJ, n 51, automne 1384/2006, pp. 91-110].

3 Partie II : 4. « NosaH-e hamsang dar dowre-ye Qājār », pp. 109-125 [MJ, nº 46, 1383/2004, pp. 76-83] ; 5. « Tajdīd-e vaqf-nāme dar dowre-ye Qājār », pp. 127-141 [MJ, n 37, 1381/2002, pp. 131-135] ; 6. « EstensāH va țabt-e asnād dar Edāre-ye Koll-e Owqāf », pp. 143-159 [MJ, n 38, 1381/2002, pp. 87-94]. 
4 En fin du volume, on trouve un court index, extrêmement utile, des termes spécialisés persans se rapportant à l'étude des documents d'archives.

INDEX

Thèmes : 4.2.1. Safavides et Qâjârs

\section{AUTEURS}

MARIA SZUPPE

CNRS - Mondes iranien et indien - Paris 